\title{
Portrait from 1931 (Robert Nisbet age 18)
}

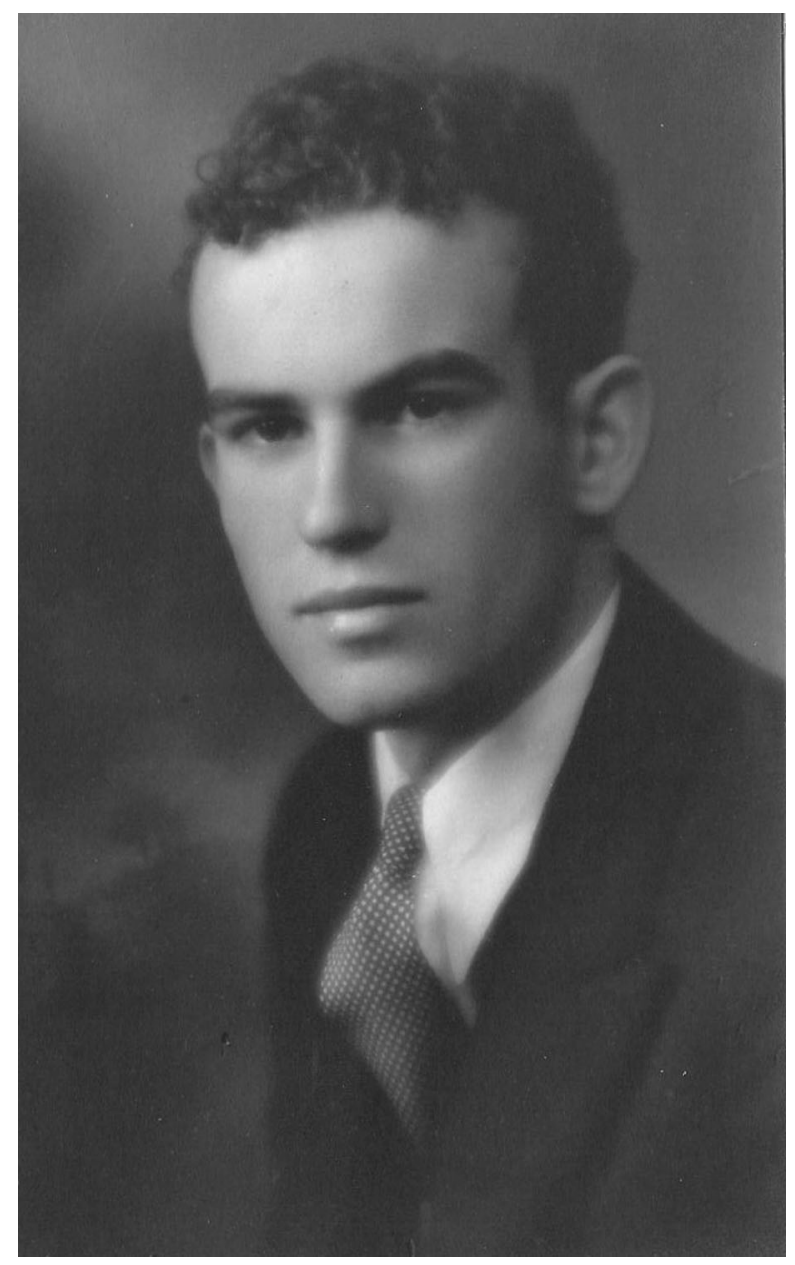

